DOI: $10.17957 / \mathrm{IJAB} / 15.1751$

http://www.fspublishers.org

\title{
Categorization of Available Cucumber Genotypes against Zucchini Yellow Mosaic Virus and Root-Knot Nematode (Meloidogyne incognita)
}

\author{
Hira Manzoor Ahmed ${ }^{1 *}$, Muhammad Ashfaq ${ }^{1}$, Tariq Mukhtar ${ }^{1}$ and Muhammad Azam Khan ${ }^{2}$ \\ ${ }^{1}$ Department of Plant Pathology, Pir Mehr Ali Shah Arid Agriculture University Rawalpindi, Pakistan \\ ${ }^{2}$ Department of Horticulture, Pir Mehr Ali Shah Arid Arid Agriculture University Rawalpindi, Pakistan \\ *For correspondence: hirabajwa30@gmail.com \\ Received 02 November 2020; Accepted 13 March 2021; Published 16 April 2021
}

\begin{abstract}
In the present study, fifteen cucumber genotypes were screened against Zucchini yellow mosaic virus (ZYMV) and root-knot nematode (Meloidogyne incognita) individually and in combinations. All the cucumber genotypes behaved differently regarding root and shoot lengths and weights, number of galls, eggmasses and ZYMV infection when inoculated with $M$. incognita and ZYMV alone and in combinations. None of the fifteen cucumber genotypes was found immune, highly or moderately resistant to $M$. incognita. Two genotypes viz., Alpha Prime and Patio were found resistant to the nematode. Contrarily, Max Pack and Beti-alpha were highly susceptible as evident by maximum galls on their roots and reductions in growth variables. Similarly, the genotypes Best PIC, Songrooh, Northern Pack, C-7 and C-5 appeared as moderately susceptible whereas Shaheen, Jakson, C-1, C-2, C-3 and C-9 genotypes showed susceptible reactions to the nematode alone. Similar trend was noticed when the genotypes were inoculated with both the nematode and the virus. Similarly, on the basis of disease rating scale, two genotypes viz., Alpha Prime and Patio were grouped as moderately resistant to ZYMV. On the other hand, eleven genotypes viz., Max Pack, Shaheen, Songrooh, Northern Pack, Jakson, Beti-alpha, C-1, C-2, C-3, C-5 and C-9 were catalogued as highly resistant while two genotypes Best PIC and C-7 were categorized as susceptible against ZYMV alone. Similarly, all the genotypes behaved in the same way when inoculated with $M$. incognita. Two genotypes Alpha Prime and Patio were found resistant against both the pathogens inoculated simultaneously and hence are recommended for cultivation. (C) 2021 Friends Science Publishers
\end{abstract}

Keywords: Galls; Resistance; Root-knot nematode; Varietal screening; ZYMV

\section{Introduction}

Cucumber (Cucumis sativus L.) is a significant seasonal vegetable which belongs to crop family of Cucurbitaceae. It is a clambering trailing plant that yields tube-shaped fruits which are mostly used in domestic cuisines. The crop is fourth in line for significance after tomatoes, cabbage and onions in Asia, while second to tomato in Europe. China was the first in yielding $60 \%$ produce in 2018 , chased by Iran, Turkey and Russia. Cucumber is cultivated over 3367 hectares with yearly produce of 68664 tons in Pakistan (FAO 2019). It is cultivated on large scale; however, its production is seriously threatened by mosaic viruses and root-knot nematodes (Ashfaq et al. 2017; Ahsan et al. 2020). Root-knot nematodes (RKN) have extensive host range and infest various seasonal and perennials (Mukhtar and Kayani 2019; Nazir et al. 2019). Approximately $90 \%$ of the horticultural crops-producing areas are infested with RKN (Trudgill et al. 2000; Tariq-Khan et al. 2017a; Mukhtar and Kayani 2020). There are more than 100 described species of RKN in which Meloidogyne incognita and $M$. javanica are commonly prevailing in tropics and subtropical zones of the globe including Pakistan (Trudgill et al. 2000; Mukhtar et al. 2017). A similar dominance of these two species has also been reported for Pakistan, with $52 \%$ M. incognita and 31\% M. javanica, 8\% M. arenaria, 7\% M. hapla and $2 \%$ other RKN species (Tariq-Khan et al. 2017b; Kayani et al. 2018). For okra grown in the central Punjab province of Pakistan, RKN incidences were $74.7 \%$ for M. incognita, $24.0 \%$ for $M$. javanica, $1.6 \%$ for $M$. arenaria and $0.8 \%$ for M. hapla (Kayani and Mukhtar 2018; Hussain and Mukhtar 2019), respectively. Similarly, cucumber grown in the Pothowar region of the Punjab province, Pakistan, was found to be infested by $78 \%$ by $M$. incognita, $19 \%$ by $M$. javanica, $2 \%$ by $M$. arenaria and $1 \%$ by M. hapla (Kayani et al. 2013; Azeem et al. 2021). From Pakistan, five RKN species have been reported so far from tropical and cooler areas. The first three species have also been found infecting vegetables in the Western Himalayan region of Azad Jammu and Kashmir (Khan et al. 2020). Furthermore, these nematodes develop disease complexes with soil borne fungal and bacterial pathogens causing vascular wilts and 
damping off in many crops and result in huge yield losses. Similarly, root-knot nematodes break resistance in cultivars resistant to wilts (Aslam et al. 2019; Asghar et al. 2020).

As the greenhouse production pattern becomes more popular, the injury instigated by RKN also becomes even more serious (Jinling et al. 2003; Mukhtar 2018; Mukhtar et al. 2021). Annual yield losses due to plant-parasitic nematodes have been estimated to exceed 173 billion US \$ and RKN share most of the damages to their credit (Elling 2013). However, nematode damage in reality might even be higher, as many growers are unaware of plant-parasitic nematodes or damage is contributed to secondary pathogens neglecting plant-parasitic nematodes being the primary cause (Jones et al. 2013).

Cucurbit viral diseases are also posing problems globally. It has been testified that viral segregations via aphids is central warning issues which deliver up to $100 \%$ crop losses. Among viruses Zucchini yellow mosaic virus (ZYMV) was the first emerging cucurbits virus which threatens cucurbit survival since 1981. It has been reported from more than 50 countries throughout the world where squashes are cultivated as traditional crop. In Pakistan, ZYMV was reported in 1993 and severe epidemics were encountered in the Punjab and NWFP during 2003-2005, causing $75-100 \%$ losses. In combination with Watermelon mosaic virus (WMV) it causes $40-50 \%$ losses in yield (Malik et al. 2006). Numerous viral strains have been studied via sap transmission together from cucurbits crops and then their host ranges were specified. The learning exposed that Cucumber mosaic virus (CMV), ZYMV, WMV, Zucchini yellow fleck virus, Squash mosaic virus, and Melon necrotic spot virus are strains which poses great threat to cucurbits.

In addition to disease complexes with soil-borne fungi and bacteria, RKN have also been found associated with viruses in a number of ways. Synergistic or antagonistic effects of RKN with virus infected plants have been reported by some workers (Iheukwumere et al. 2008; Youssef et al. 2011). Therefore, the present study was planned to catalogue available cucumber genotypes against Zucchini yellow mosaic virus and root-knot nematode individually and in combination.

\section{Materials and Methods}

The present study was carried out at Plant Virology Laboratory, Department of Plant Pathology, Pir Mehr Ali Shah Arid Agriculture University Rawalpindi (33.5651 ${ }^{\circ} \mathrm{N}$, $\left.73.0169^{\circ} \mathrm{E}\right)$, Pakistan. Zucchini yellow mosaic virus (ZYMV) was collected from Plant Virology Laboratory, Department of Plant Pathology while M. incognita was taken from Plant Nematology Laboratory, Pir Mehr Ali Shah Arid Agriculture University Rawalpindi, Pakistan. Cucumber germplasm (Shaheen, Best pick, Songrooh, Alpha Prime, Northern Pack, C-1, C-2, C-3, C-5, C-7, C-9, Beti alpha, Patio, Jakson and Max Pack) were collected from Federal Seed Certification Department, Islamabad, Pakistan.

\section{Nematode inoculum}

The inoculm of root-knot nematode used in the evaluation of cucumber germplasm was obtained from the already identified culture maintained in the Nematology lab. The nematode was further mass produced on tomato cv. Money Maker in pots in the greenhouse of the Department of Plant Pathology, Pir Mehr Ali Shah Arid Agriculture University, Rawalpindi, Pakistan at $25^{\circ} \mathrm{C} \pm 2$. For collection of eggs, $M$. incognita infected roots were removed from pots, washed with tap water, cut into approximately $1-2 \mathrm{~cm}$ pieces and vigorously shaken in a bottle containing $0.5 \% \mathrm{NaOCI}$ for 5 min. The eggs were collected on a $38 \mathrm{~mm}$ sieve and washed in a beaker. The egg suspension was poured onto an extraction tray and juveniles were collected. The freshly hatched second stage juveniles were standardized and concentrated.

\section{Maintenance of viral inoculum}

For the maintenance of ZYMV, mechanical transmission method was adopted (Dheepa and Paranjothi 2010). Leaves infected with ZYMV were separately used for the sap extraction. Infected leaves were macerated in $0.1 \mathrm{M}$ phosphate buffer ( $\mathrm{pH} 7.0$ ) containing $1.0 \%$ sodium sulphite (1:2 W/V). Prepared inoculum was filtered through double layer muslin cloth. Sap was applied on healthy leaves of cucumber (Best Pick) which were already dusted with 600 mesh carborandum powder. Inoculated plants were kept under greenhouse conditions at $25-27^{\circ} \mathrm{C}$ for 30 days. Plants were regularly inspected for the disease development.

\section{Screening of cucumber genotypes against ZYMV and M. incognita}

The cucumber germplasm was screened against ZYMV and RKN alone and conjointly. Sterilized seeds of cucumber germplasm were sown in earthen pots $(15 \mathrm{~cm}$ diameter $)$ containing sterilized soil. Seven days after emergence, cucumber seedlings were inoculated with $10 \mathrm{~mL}$ nematode suspension $(2,000 \mathrm{~J} 2)$ by pouring the suspension in the plant root regions while virus inoculum was applied at 2-4 leaf stage by mechanical inoculation method in triplicate. Rests of the practices were kept same for all the treatments and plants were watered keeping in view the requirements. All the treated and untreated plant pots were kept under insect pest free glasshouse conditions at $25-27^{\circ} \mathrm{C}$ for symptoms development. Data recording was done seven weeks after inoculations. All the cucumber genotypes were categorized using disease rating scale proposed by Ashfaq et al. (2007). A modification of rating scale based on number of galls proposed by Mukhtar et al. (2013) was used to assess the degree of resistance or susceptibility of cultivars. 
Data on viral infection percentage, growth parameters viz., root length, shoot length, root and shoot weight was taken while nematode reproduction parameters like number of galls and eggmasses was also recorded. Reciprocal effect of ZYMV and nematode M. incognita infection was also investigated. All the data were subjected to analysis of variance using the GenStat package 2009 , (12 ${ }^{\text {th }}$ edition $)$ version 12.1.0.3278 (www.vsni.co.uk). The means were compared by Duncan's Multiple Range Test at 5\%.

\section{Results}

Effect of M. incognita and ZYMV on growth variables of cucumber genotypes

All the cucumber genotypes behaved differently regarding root and shoot lengths and weights when inoculated with $M$. incognita alone. The maximum root lengths were recorded with Patio, Alpha Prime and C-1 while the root weights were found to be the maximum in case of C-9 and Betialpha. On the other hand, root lengths were found to be the minimum in case of C-9 and Beti-alpha and root weights were the minimum in case of $\mathrm{C}-1$ and Patio as shown in Fig. 1. Similarly, C-1, Patio and Alpha Prime showed the maximum shoot lengths while in case of shoot weights no significant differences were observed among cucumber genotypes as shown in Fig. 2.

Likewise, cucumber genotypes varied significantly regarding root and shoot lengths and weights when inoculated with ZYMV alone. Root lengths and weights were the maximum in Alpha Prime and Patio genotypes while the minimum lengths and weights were recorded in case of Max Pack and Beti-alpha genotypes (Fig. 3). On the other hand, all the cucumber genotypes behaved similarly in case of shoot lengths and weights with few exceptions as shown in Fig. 4. When cucumber genotypes were inoculated with both the pathogens, similar results were obtained regarding root lengths and weights shoot lengths and weights (Fig. 5 and 6).

Effect of $M$. incognita and ZYMV on galls and eggmasses

The maximum galls and eggmasses were produced by $M$. incognita on Beti-alpha followed by Max Pack while galls and eggmasses were the minimum in case of Alpha Prime and Patio. The rest of the genotypes were found intermediate regarding these parameters (Fig. 7). When cucumber genotypes were inoculated with both the pathogens, similar results were obtained regarding number of galls and eggmasses (Fig. 8) as in case of individual inoculation of the pathogens with few exceptions.

\section{Effect of M. incognita and ZYMV on virus infection}

Maximum ZYMV infection was observed in Beti-alph followed by Jackson, Max Pack and C-2 while the infection

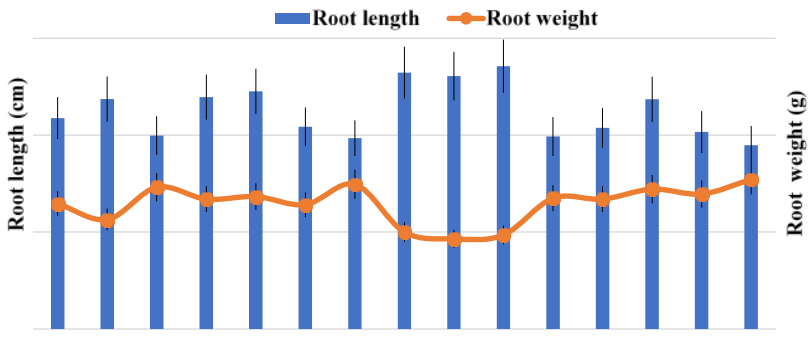

Fig. 1: Effect of root-knot nematode alone on root length and root weight of cucumber genotypes

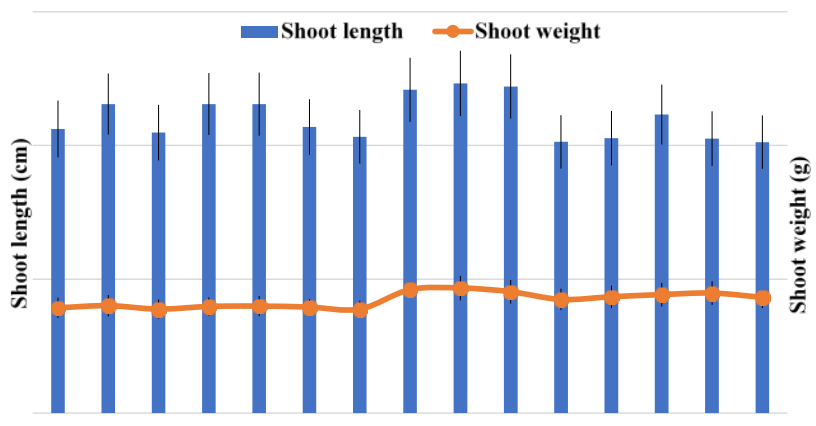

Fig. 2: Effect of root-knot nematode alone on shoot length and shoot weight of cucumber genotypes

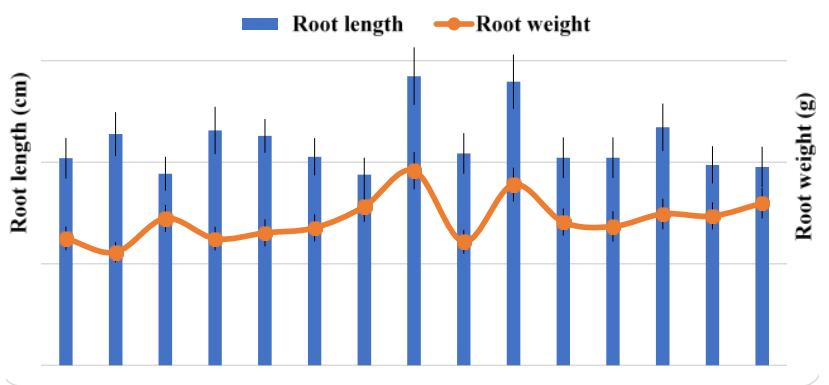

Fig. 3: Effect of ZYMV alone on root length and root weight of cucumber genotypes

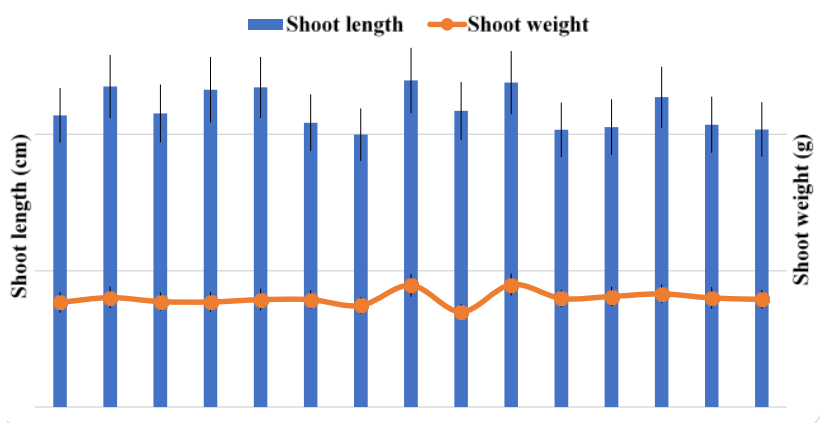

Fig. 4: Effect of ZYMV alone on shoot length and shoot weight of cucumber genotypes

was found to be the minimum in case of Alpha Prime and Patio (Fig. 9). When cucumber genotypes were inoculated with both the pathogens, similar results were obtained 


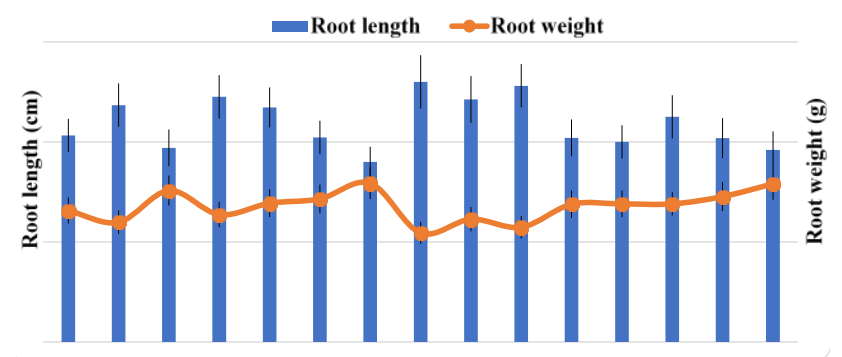

Fig. 5: Combined effect of root-knot nematode and ZYMV on root length and root weight of cucumber genotypes

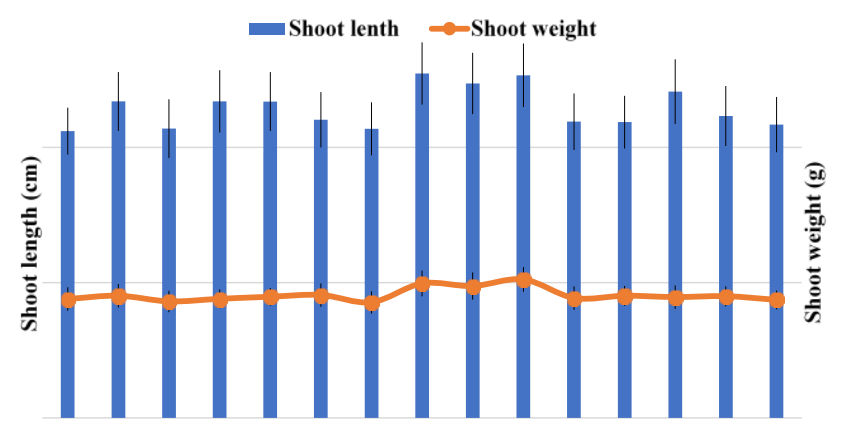

Fig. 6: Combined effect of root-knot nematode and ZYMV on shoot length and shoot weight of cucumber genotypes

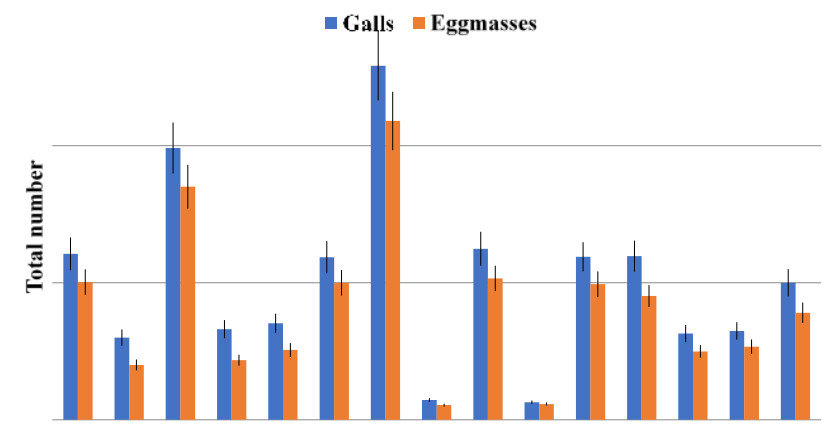

Fig. 7: Effect of cucumber genotypes on number of galls and eggmasses by root-knot nematode

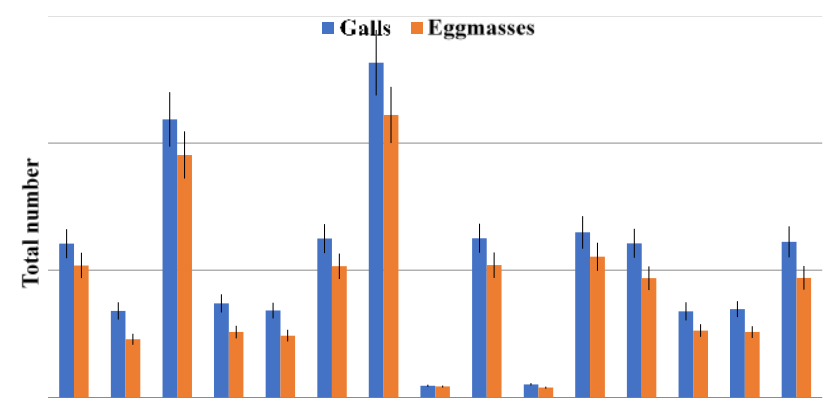

Fig. 8: Effect of cucumber genotypes on number of galls and eggmasses by root-knot nematode when inoculated with ZYMV

regarding ZYMV infection as in case of individual inoculation of the pathogens with few exceptions (Fig. 10).

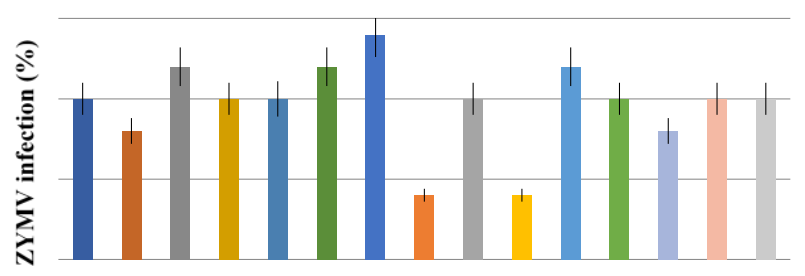

Fig. 9: Effect of cucumber genotypes on ZYMV infection

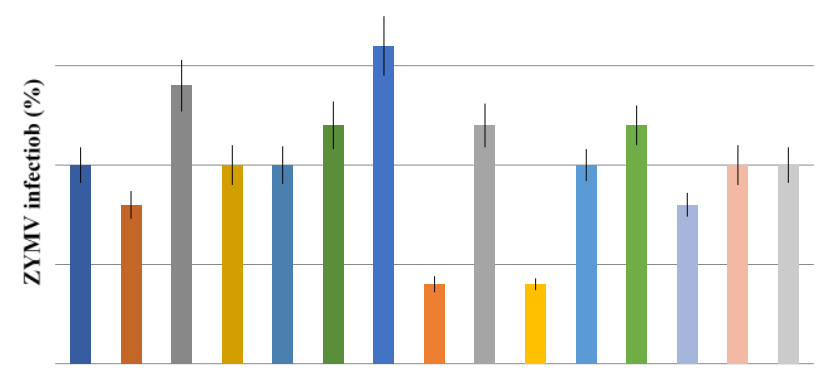

Fig. 10: Effect of cucumber genotypes on ZYMV infection when inoculated with $M$. incognita

\section{Reaction of cucumber genotypes to $M$. incognita and ZYMV}

None of the fifteen cucumber genotypes was found immune, highly or moderately resistant to $M$. incognita. Two genotypes viz., Alpha Prime and Patio were found resistant to the nematode. Contrarily, Max Pack, Beti-alpha were highly susceptible as evident by maximum galls (> $100)$ on their roots and reductions in growth variables. Similarly, the genotypes Best PIC, Songrooh, Northern Pack, C-7 and C-5 appeared as moderately susceptible whereas Shaheen, Jakson, C-1, C-2, C-3 and C-9 genotypes showed susceptible reactions to the nematode alone. Similar trend was noticed when the genotypes were inoculated with both the nematode and the virus (Table 1).

Similarly, on the basis of disease rating scale, two genotypes viz., Alpha Prime and Patio were grouped as moderately resistant to ZYMV. On the other hand, eleven genotypes viz., Max Pack, Shaheen, Songrooh, Northern Pack, Jakson, Beti-alpha, C-1, C-2, C-3, C-5 and C-9 were catalogued as highly resistant while two genotypes Best PIC and C-7 were categorized as susceptible against ZYMV alone. Similarly, all the genotypes behaved in the same way when inoculated with M. incognita (Table 2).

\section{Discussion}

Cucumber is an important vegetable and one of the most popular members of Cucurbitaceae family. Low yield of cucumber is mainly attributed to viral pathogens and nematodes. The most frequent and economically important pathogens; Zucchini yellow mosaic virus and $M$. incognita are highly aggressive to cucumber crop. In the present study 
Response of Cucumber Genotypes against ZYMV and RKN / Intl J Agric Biol, Vol 25, No 5, 2021

Table 1: Response of cucumber genotypes against root-knot nematodes (alone) and combined inoculation of RKN and ZYMV

\begin{tabular}{llll}
\hline Number of galls & Reaction & Inoculation of RKN alone & Combined inoculation of RKN and ZYMV \\
\hline 0 & Immune & - & - \\
$1-2$ & Highly Resistant & - & - \\
$3-10$ & Resistant & Alpha Prime, Patio & Alpha Prime, Patio \\
$11-30$ & Moderately Resistant & - & - \\
$31-70$ & Moderately Susceptible & Best PIC, Songrooh, Northern Pack, C-7, C-5 & Best PIC, Songrooh, Northern Pack, C-7, C-5 \\
$71-100$ & Susceptible & Shaheen, Jakson, C-1, C-2, C-3, C-9 & Shaheen, Jakson, C-1, C-2, C-3, C-9 \\
$>100$ & Highly Susceptible & Max Pack, Beti-alpha & Max Pack, Beti-alpha \\
\hline
\end{tabular}

Table 2: Response of cucumber genotypes against ZYMV (alone) and combined inoculation of ZYMV and RKN

\begin{tabular}{llll}
\hline Description & Reaction & Inoculation of ZYMV alone & Combined inoculation of ZYMV and RKN \\
\hline $\begin{array}{l}\text { 0\% infection, all plants free of Highly Resistant } \\
\text { symptoms }\end{array}$ & - & - \\
$1-10 \%$ plants infected & Resistant & - & - \\
$>10-20 \%$ plants infected & Moderately Resistant & Alpha Prime, Patio & Alpha Prime, Patio \\
$>$ 20-30\% plants infected & Moderately Susceptible & - & - \\
$>30-40 \%$ plants infected & Susceptible & Best PIC, C-7 & Best PIC, C-7 \\
More than 40\% plants infected & Highly Susceptible & MaxPack, Shaheen, Songrooh, Northern Pack, MaxPack, Shaheen, Songrooh, Northern Pack, \\
& & Jakson, Beti-alpha, C-1, C-2, C-3, C-5, C-9 & Jakson, Beti-alpha, C-1, C-2, C-3, C-5, C-9 \\
\hline
\end{tabular}

fifteen cucumber genotypes were screened against ZYMV and root-knot nematode individually and in combinations. All the cucumber genotypes behaved differently regarding root and shoot lengths and weights, number of galls, eggmasses and ZYMV infection when inoculated with $M$. incognita and ZYMV alone and in combinations. The genotypes also showed varying responses to nematode and the virus when inoculated singly and conjointly.

In the present study, all the treated genotypes showed decreases in plant growth parameters as compared to untreated control. This might be due to penetration of second stage juveniles in the roots and their migration to vascular bundles. The nematode induced severe root galling which affected the utilization efficiency of water and nutrients and the partitioning of photosynthetic products (Williamson and Hussey 1996). Reduced supply of nutrients to the roots as a result of viral and nematode infections has also been reported (Varshney et al. 2005). Another study showed that combined infection of nematode and virus significantly reduced numbers of galls and eggmasses in Trifolium repens by combined infection (McLaughlin et al. 1993) probably due to changes induced by the pathogens in the plant physiology that resulted in to suppressed nematode development (Goswami et al. 1994). The suppressive effects of ZYMV, CMV and other viruses on the nematode in cucumber and other crops have also been confirmed by many workers (Iheukwumere et al. 2008; Youssef et al. 2011). Patel and Patel (1995) reported that combined infection of TMV and root-knot nematodes caused accelerated reduction of protein nitrogen, total nitrogen and nicotine contents and a greater improvement in total sugar content over singly infected plants. Simultaneous infection with virus and nematode had a more pronounced effect on these chemical constituents suggesting that quality of bidi tobacco would be greatly impaired. McLaughlin and Windhan (1996) studied the effects of peanut stunt virus, $M$. incognita, and drought on growth and persistence of white clover and reported that drought stress, M. incognita, and peanut stunt virus acted independently in reducing forage productivity and persistence. In a previous study, Walker and Wallace (1975) evaluated the influence of tobacco ringspot virus and $M$. javanica, alone and in combination on the growth and mineral content of French beans. Plants infected with tobacco ringspot virus were clearly intolerant to infection as indicated by their stunted growth and their marked difference in content of phosphorus, chlorine, copper, manganese and zinc from uninfected plants. In contrast, plants infected with $M$. javanica were tolerant to infection by this parasite; no difference was detected between nematode-infected plants and the uninfected controls. Koulagi et al. (2020) worked on host-delivered RNA interference in tomato for mediating resistance against M. incognita and Tomato leaf curl virus and provided an evidence for generating resistance through RNAi against multiple biotic stresses. Previously, Tobacco rattle virus has also been reported to mediate gene silencing in a plant parasitic root-knot nematode (Dubreuil et al. 2009).

Application of RKN to cucumber genotypes formed galls and eggmasses on the roots. The galls and eggmasses were greater in plants infected with the nematode only as compared to those infected with both the nematode and virus. This might be due to reduced supply of nutrients to the roots as a result of virus attack (Varshney et al. 2005). Present findings are in line with those of Ahmed et al. (2007) who reported similar results. RKN interaction with fungi, bacteria and viruses have been listed and documented and can synergistically provoke certain diseases in many crop plants. These pathogens especially viruses occur in complexes and cause colossal losses through reduction in growth and yield of the crop. M. incognita is not a vector of plant viruses but under field conditions, it was observed that $M$. incognita occurred concomitantly with viruses in the same plant, as is the case with cucumber. The negative interaction exists between the nematode and virus. The virus may have stressed the plant thus reduced multiplication and infectivity of nematode (Goswami et al. 1994). 
It has been often observed that a particular cultivar resistant to some bacterial pathogens becomes susceptible in the presence of root-knot nematodes. For example, wilt causing bacteria produce some toxins in host tissue which induce the wilt symptoms. In resistant cultivars, the mechanism of production of the toxins is inhibited or it is detoxified by the natural defense of the plant, hence, wilting does not take place. However, the nematode infections induced certain changes in host physiology, leading to failure of detoxification mechanism of the resistant cultivars, and the plants become susceptible. An eggplant cultivar, Pusa purple cluster, highly resistant to Pseudomonas solanaecarum becomes susceptible in the presence of $M$. incognita. Similarly, field resistance in potato to $P$. solanaecarum was broken when the plants were infected with $M$. incognita. Wilt fungus resistant cultivars also become susceptible in the presence of root-knot nematodes. Wilt resistant cotton cultivars succumbed to Fusarium in the presence of $M$. incognita. Tomato cv. Chesapeake resistant to Fusarium wilted in the presence of the same nematodes' species. The wilt severity, however, varied with the nematode species, presence of $M$. hapla caused $60 \%$ wilting, whereas $100 \%$ wilting occurred with M. incognita (Khan 2008).

\section{Conclusion}

It is concluded from the present study that combined infection of root-knot nematode and ZYMV caused reductions in growth variables of fifteen cucumber genotypes. Two genotypes Alpha Prime and Patio were found resistant against both the pathogens inoculated simultaneously and hence are recommended for cultivation. Furthermore, these cultivars could be used in breeding programs to develop new cultivars resistant to both the nematode and the virus.

\section{Acknowledgements}

This work has been funded by the IRSIP Program of Higher Education Commission Pakistan and is highly acknowledged.

\section{Author Contributions}

HMA and MA designed the study, executed experimental work, analyzed the data and prepared the manuscript. TM designed the study, supervised the experimental work and edited the manuscript. All the authors edited the manuscript.

\section{Conflict of Interest}

The authors declare that there is no conflict of interest of any type i.e., among authors, with the institution of authors, with previous publication etc.

\section{Data Availability}

The authors keep all the data which will be available on request.

\section{Ethics Approval}

The study does not involve animals or humans and therefore, does not involve any ethical approval.

\section{References}

Ahmed AA, WMA El-Nagdi, MMA Youssef (2007). Potential role of Xiphinema americanum and Meloidogyne incognita in transmission of peach rosette mosaic virus. J Agric Sci Mansoura Univ 32:2001-2002

Ahsan M, M Ashfaq, T Mukhtar, NA Abbasi (2020). Current status and genetic variability of cucumber mosaic cucumovirus (CMV) isolates infecting major cucurbits and solanaceous vegetables in Pothwar region of Pakistan. Pak J Agric Sci 57:1353-1361

Asghar A, T Mukhtar, MU Raja, A Gulzar (2020). Interaction between Meloidogyne javanica and Ralstonia solanacearum in chili. Pak $J$ Zool 52:1525-1530

Ashfaq M, A Saleem, M Waqas, T Mukhtar (2017). Natural occurrence and host range studies of Cucumber Mosaic Virus (CMV) infecting ornamental species in Rawalpindi-Islamabad area of Pakistan. Philipp Agric Sci 100:55-61

Ashfaq M, MA Khan, SM Mughal, N Javed, T Mukhtar, M Bashir (2007). Evaluation of urdbean germplasm for resistance against Urdbean leaf crinkle virus. Pak J Bot 39:2103-2111

Aslam MN, T Mukhtar, M Jamil, M Nafees (2019). Analysis of aubergine germplasm for resistance sources to bacterial wilt incited by Ralstonia solanacearum. Pak J Agric Sci 56:119-122

Azeem W, T Mukhtar, T Hamid (2021). Evaluation of Trichoderma harzianum and Azadirachta indica in the management of Meloidogyne incognita in tomato. Pak J Zool 53:119-125

Dheepa R, S Paranjothi (2010). Transmission of Cucumber mosaic virus (CMV) infecting banana by aphid and mechanical methods. Emir J Food Agric 22:117-129

Dubreuil G, M Magliano, MP Dubrana, J Lozano, P Lecomte, B Favery, P Abad, MN Rosso (2009). Tobacco rattle virus mediates gene silencing in a plant parasitic root-knot nematode. J Exp Bot 60:4041-4050

Elling AA (2013). Major emerging problems with minor Meloidogyne species. Phytopathology 103:1092-1102

FAO (2019). http://www.fao.org/faostat/en/\#data/QC

Goswami BK, S Singh, VS Verma (1994). Interaction of a mosaic virus with root-knot nematode Meloidogyne incognita in Vigna sinensis. Nematologica 20:366-377

Hussain MA, T Mukhtar (2019). Root-knot nematodes infecting okra in major vegetable growing districts of Punjab, Pakistan. Pak J Zool $51: 1137-1143$

Iheukwumere CC, KE Dashiell, HJW Mutsaers (2008). Effects of single and combined infection of soybean mosaic virus and Meloidogyne incognita on soybean and replication and pathogenicity of both pathogens. Nematol Mediterr 36:25-30

Jinling L, J Han, S Longhua, H Xianqi, Z Zhirong, W Xinrong (2003). Identification of species and race of root-knot nematodes on crops in southern China. J Huazhong Agric Univ 22:544-548

Jones JT, A Haegeman, EGJ Danchin, HS Gaur, J Helder, MGK Hones, RN Perry (2013). Top 10 Plant-parasitic nematodes in molecular plant pathology. Mol Plant Pathol 14:946-961

Kayani MZ, T Mukhtar (2018). Reproductivity of Meloidogyne incognita on fifteen cucumber cultivars. Pak J Zool 50:1717-1722

Kayani MZ, T Mukhtar, MA Hussain (2018). Interaction between nematode inoculum density and plant age on growth and yield of cucumber and reproduction of Meloidogyne incognita. Pak J Zool 50:897-902 
Kayani MZ, T Mukhtar, MA Hussain, MI Haque (2013). Infestation assessment of root-knot nematodes (Meloidogyne spp.) associated with cucumber in the Pothowar region of Pakistan. Crop Prot 47:49-54

Tariq-Khan M, T Mukhtar, A Munir, J Hallmann, H Heuer (2020). Comprehensive report on the prevalence of root-knot nematodes in the Poonch division of Azad Jammu and Kashmir, Pakistan. J Phytopathol 168:322-336

Tariq-Khan M, A Munir, T Mukhtar, J Hallmann, H Heuer (2017a). Distribution of root-knot nematode species and their virulence on vegetables in northern temperate agro-ecosystems of the Pakistani-administered territories of Azad Jammu and Kashmir. $J$ Plant Dis Prot 124:201-212

Tariq-Khan M, N Javed, ST Sahi, T Mukhtar, SA Khan, W Ashraf (2017b). Glomus mosseae (Gerd\& Trappe) and neemex reduce invasion and development of Meloidogyne incognita. Pak J Zool 49:841-847

Koulagi R, S Banerjee, BH Gawade, AK Singh, PK Jain, S Praveen, K Subramaniam, A Sirohi (2020). Host-delivered RNA interference in tomato for mediating resistance against Meloidogyne incognita and Tomato leaf curl virus. Plant Cell Tiss Org Cult 143:345-361

Malik AH, S Mansoor, S Iram, RW Briddon, Y Zafar (2006). A severe outbreak of melon yellow mosaic disease caused by Zucchini yellow mosaic virus in the Punjab province of Pakistan. Plant Pathol 55:285-285

McLaughlin MR, GL Windham (1996). Effects of peanut stunt virus, Meloidogyne incognita, and drought on growth and persistence of white clover. Phytopathology 86:1105-1111

McLaughlin MR, GL Windhan, AS Heagle (1993). Response of Trifolium repens clones to infection by Meloidogyne incognita and peanut stunt virus. J Nematol 25:869-875

Mukhtar T (2018). Management of root-knot nematode, Meloidogyne incognita, in tomato with two Trichoderma species. Pak J Zool 50:1589-1592

Mukhtar T, MZ Kayani (2020). Comparison of the damaging effects of Meloidogyne incognita on a resistant and susceptible cultivar of cucumber. Bragantia 79:83-93
Mukhtar T, MZ Kayani (2019). Growth and yield responses of fifteen cucumber cultivars to root-knot nematode (Meloidogyne incognita) Acta Sci Pol Hortic Cult18:45-52

Mukhtar T, MZ Kayani, MA Hussain (2013). Response of selected cucumber cultivars to Meloidogyne incognita. Crop Prot 44:13-17

Mukhtar T, MT Khan, MN Aslam (2021). Bioefficacy of Trichoderma species against Javanese root-knot nematode, Meloidogyne javanica in green gram. Gesunde Pflanz 85:1-8 In Press

Mukhtar T, M Arooj, M Ashfaq, A Gulzar (2017). Resistance evaluation and host status of selected green gram genotypes against Meloidogyne incognita. Crop Prot 92:198-202

Nazir K, T Mukhtar, H Javed (2019). In vitro effectiveness of silver nanoparticles against root-knot nematode (Meloidogyne incognita) Pak J Zool 51:2077-2083

Patel KA, BN Patel (1995). Effect of tobacco mosaic virus and root-knot nematode infection on chemical constituents of bidi tobacco. Ind $J$ Mycol Plant Pathol 25:228-230

Trudgill DLG, VC Bala, A Blok, A Daudi, KG Davies, SR Gowen, M Fargette, JD Madulu, T Mateille, W Mwageni, C Netscher, MS Phillips, A Sawadogo, CG Trivino, E Voyoukallou (2000). The importance of tropical root-knot nematodes (Meloidogyne spp.) and factors affecting the utility of Pasteuria penetrans as a biocontrol agent. Nematology 2:823-845

Varshney S, RC Pandey, RK Panday, BK Dwivedi, V Singh (2005) Interaction between mungbean, yellow mosaic virus and root knot nematode on growth of mungbean plants. Pak J Nematol 23:93-98

Walker GE, HR Wallace (1975). The influence of root-knot nematode (Meloidogyne javanica) and tobacco ringspot virus on the growth and mineral content of French beans (Phaseolus vulgaris). Nematologica 21:455-462

Williamson VM, RS Hussey (1996). Nematode pathogenesis and resistance in plants. Plant Cell 8:1735-1745

Youssef MMA, WMA El-Nagdi, AA Ahmed (2011). Interaction of cucumber mosaic virus with the root-knot nematode, Meloidogyne incognita and effects of certain medicinal and aromatic plants on infected cucumbers. Nematol Mediterr 39:73-80 